..... Jug, Beljo Lučić, Čavlović: Čimbenici koji utječu na rastresitost usitnjenog materijala...

Matija Jug, Ružica Beljo Lučić, Anka Ozana Čavlovićl

\title{
Čimbenici koji utječu na rastresitost usitnjenog materijala nastalog blanianjem drva
}

\section{Influencing Factors on Looseness of Chipped Material Generated during Wood Planing}

\author{
Izvorni znanstveni rad • Original scientific paper \\ Prispjelo-received: 21. 10. 2015. \\ Prihvaćeno-accepted: 5. 5. 2016. \\ UDK: $630 * 812.22 ; 630 * 839.811$ \\ doi:10.5552/drind.2016.1537
}

\begin{abstract}
SAŽETAK • Poznavanje faktora rastresitosti $i$ nasipne gustoće usitnjenog materijala nastaloga u procesu mehaničke obrade drva važno je radi optimalnog izbora sredstava za rukovanje, transportiranje i skladištenje, ali $i$ radi trajnosti $i$ kvalitete usitnjenog drva kao sirovine za izradu drvnih proizvoda od usitnjenog drva. Faktor rastresitosti usitnjenoga drvnog materijala definiran je kao omjer volumena usitnjenog materijala $i$ cjelovitog drva od kojega je nastao. U radu je analiziran utjecaj posmične brzine, prednjeg kuta rezne oštrice $i$ vrste drva na faktor rastresitosti usitnjene blanjevine. Odabrani su uzorci jelovine, hrastovine, parene bukovine i termički modificirane bukovine (pri temperaturi od $212^{\circ} \mathrm{C}$ ) dobiveni blanjanjem pri četiri posmične brzine $\left(v_{p 1}=6 ; v_{p 2}=\right.$ $\left.12 ; v_{p 3}=18 i v_{p 4}=24 \mathrm{~m} / \mathrm{min}\right)$ i tri prednja kuta oštrice $\left(\gamma_{1}=15^{\circ} ; \gamma_{2}=20^{\circ} i \gamma_{3}=25^{\circ}\right)$. Povećanje posmične brzine utjecalo je na smanjenje faktora rastresitosti samo za uzorke bukovine i jelovine. Utjecaj prednjeg kuta oštrice pri blanjanju različitih vrsta drva nije jednoznačan. Debljina strugotine nije se pokazala najvažnijim činiteljem koji utječe na faktor rastresitosti nego je to smjer rezanja u odnosu prema smjeru vlakanaca drva te oblik nastale čestice i njezina lomljivost. Najveći faktor rastresitosti dobiven je za blanjevinu jelovine pri najmanjoj posmičnoj brzini $\left(f_{r}=28,42\right)$, a najmanji faktor rastresitosti zamijećen je za blanjevinu termički modificirane bukovine $\left(f_{r}=\right.$ 2,62). Dobiveni rezultati za faktor rastresitosti blanjevine višestruko su veći od navoda u literaturi.
\end{abstract}

Ključne riječi: usitnjeno drvo, faktor rastresitosti, nasipna gustoća, posmična brzina, blanjanje

\begin{abstract}
It is necessary to know the looseness factor and bulk density of chipped wood generated in the mechanical wood processing to make the optimal choice of equipment for handling, transportation and storage, and also to determine the durability and quality of chipped wood as raw material. The looseness factor of chipped wood is defined as the ratio of volume of chipped wood and volume of solid wood. This paper presents the analysis of the effect of feed speed, rake angle and wood species on the looseness factor of chips generated in planing solid wood. Selected samples of chipped pine-wood, oak-wood, steamed and thermally modified beech-wood (at temperature of $\left.212^{\circ} \mathrm{C}\right)$ were generated in planing at four different feed speeds $\left(v_{p 1}=6 ; v_{p 2}=12 ; v_{p 3}=18 i v_{p 4}=24\right.$ $\mathrm{m} / \mathrm{min})$ and three rake angles $\left(\gamma_{1}=15^{\circ} ; \gamma_{2}=20^{\circ} i \gamma_{3}=25^{\circ}\right)$. The increase of feed speed only affects the reduction of the looseness factor for beech-wood and fir-wood. The impact of the rake angle during planing of researched wood species is not entirely clear. The presumed significant influence of cutting depth on the looseness factor was not established but significant influence was found of the cutting direction relative to the wood grain direction, the particles shape and their ability to fragmentation. The maximum looseness factor was obtained for chipped
\end{abstract}

\footnotetext{
Autori su znanstveni novak, profesorica i izvanredna profesorica Šumarskog fakulteta Sveučilišta u Zagrebu, Zagreb, Hrvatska.

Authors are junior researcher, professor and associate professor at Faculty of Forestry, University of Zagreb, Croatia.
} 
wood generated during planing of fir-wood at minimum feed speed $\left(f_{r}=28.42\right)$ and the lowest in planing thermally modified beech-wood $\left(f_{r}=2.62\right)$. All obtained looseness factors were several times higher than those quoted in the literature.

Key words: chipped wood, looseness factor, bulk density, feed speed, planing

\section{UVOD \\ 1 INTRODUCTION}

U posljednje su vrijeme šumska biomasa, kao i drvna biomasa iz drvoprerađivačke industrije, postali vrlo važan obnovljivi izvor energije jer su ekološki prihvatljiviji od fosilnih goriva. Uglavnom se upotrebljavaju u energanama za zagrijavanje pogona, dobivanje toplinske energije za sušenje drvnog materijala u sušionicama, za proizvodnju drvnih briketa i peleta te, $\mathrm{u}$ novije vrijeme, za proizvodnju električne energije u kogeneracijskim postrojenjima. Biomasa se usitnjava iveračima te transportira i skladišti u rasutom stanju. Pri tome se, osim o ekonomičnosti procesa rukovanja i transportiranja usitnjenog materijala, vodi briga i o očuvanju njegove kvalitete. Vrlo je korisno poznavati svojstva usitnjenog drva važna za transport i skladištenje (kao što su nasipna gustoća i faktor rastresitosti). Usitnjeno drvo pripada skupini sipkih materijala. Prema definiciji (Sever, 1988.; Madjarević, 1969.), sipki je materijal tvar koja se može presipavati, lopatati, hrptati i sl. a da to bitno ne smanjuje njezinu uporabnu vrijednost.

Permeabilnost usitnjenog materijala utječe na njegovu trajnost i očuvanje kvalitete ovisno o granulometrijskom sastavu, poroznosti, sadržaju vode u drvu i nasipnoj gustoći materijala. Poznato je da povećanje sadržaja vode u drvu za $10 \%$ drastično smanjuje permeabilnost usitnjenog materijala te da je permeabilnost veća za krupnije čestice odnosno za usitnjeni materijal manje nasipne gustoće (Shang i dr., 1999.).

Pri projektiranju kapaciteta transportnih sredstava, izboru uređaja za odvajanje čestica (ciklona, filtara i dr.) te pri proračunu opterećenja i tlaka na stijene bunkera i dr. treba poznavati nasipnu gustoću usitnjenog materijala (Sever, 1988.).

Faktor rastresitosti jedno je od važnih svojstava sipkog materijala, a označava omjer volumena usitnjenog materijala i cjelovitog drva od kojega nastaje. Nasipna gustoća i faktor rastresitosti ovise o svojstvima drva, sadržaju vode u njemu, o vrsti mehaničke obrade drva (blanjanje, piljenje, glodanje, brušenje i dr.) te o parametrima procesa rezanja. Nasipna gustoća usitnjenog materijala povećava se sa smanjenjem veličine čestica (Beljo Lučić i dr., 2005.). Nasipna gustoća i faktor rastresitosti ovise o granulometrijskom sastavu usitnjenog materijala, na koji pak utječu brojni parametri procesa rezanja - vrsta drva, smjer rezanja s obzirom na smjer vlakanaca, posmična brzina, brzina rezanja, geometrija alata i dr. Prema Palmqvistu i Gustafssonu (1999.), smanjenjem debljine strugotine i sadržaja vode u drvu povećava se udio sitnih čestica usitnjenog materijala pri blanjanju različitih vrsta drva. Treba izbjegavati debljinu strugotine manju od $0,1 \mathrm{~mm}$ jer se zbog drastično većega jediničnog otpora rezanja prebr- zo zatupljuje rezna oštrica i nastaju vrlo sitne drvne čestice sklone lebdenju u okolnom zraku.

Prema teoriji rezanja, debljina strugotine proporcionalna je posmičnoj brzini i obrnuto proporcionalna brzini rezanja. Iz dosadašnjih granulometrijskih analiza usitnjenog materijala nastaloga pri otvorenom rezu (blanjanje, obodno glodanje i brušenje) poznato je da povećanje posmične brzine pozitivno utječe na stvaranje većeg broja krupnijih čestica i manjeg broja sitnih čestica, manjih od 0,1 mm (Kopecky and Rousek, 2007.; Beljo Lučić i dr., 2007a). Međutim, rezultati drugih istraživanja pokazuju suprotno (Hemmilä i dr., 2002.): pri glodanju nižim brzinama nastao je usitnjeni materijal s manje sitnijih čestica. Također se pokazalo da smanjenje posmične brzine rezultira smanjenjem udjela sitnijih čestica u usitnjenome materijalu, kao i to da utjecaj posmične brzine na granulometrijski sastav nije jasan. Istraživanja Varge i dr. (2004.) pokazala su da s povećanjem posmične brzine i brzine glodanja $u$ usitnjenom materijalu nastaje više sitnijih čestica.

Složenost problematike očituje se u brojnosti čimbenika koji utječu na usitnjavanje drva.

Rezultati granulometrijske analize usitnjenog materijala nastaloga pri zatvorenom rezu (piljenje) pokazali su da povećanje posmične brzine ne rezultira uvijek nastankom većeg broja krupnijih čestica u smjesi te da smjer rezanja u odnosu prema smjeru vlakanaca i obliku nastale čestice imaju veći utjecaj na granulometrijski sastav negoli debljina strugotine. Promjenom položaja radnog stola pri piljenju kružnom pilom mijenja se smjer rezanja u odnosu prema vlakancima pa tako nastaju čestice različitog oblika - kraće i deblje čestice pri rezanju okomito na vlakanca ili dulje i tanje čestice pri rezanju uzduž vlakanaca (Beljo Lučić i dr., 2007b). Neposredno nakon nastanka čestice u zatvorenom rezu dolazi do dodatnog usitnjavanja ovisno o obliku čestice.

Istraživanjem utjecaja smjera brušenja na usitnjavanje čestica smrekovine i borovine pokazalo se da bruševina značajno manje nasipne gustoće nastaje pri brušenju u smjeru vlakanaca negoli poprečno na vlakanca (Očkajová i dr., 2008.; Dolny i Rogoziński, 2011.). Pritom je građa drva uzrok nastanka čestica vlaknastoga (omjer duljina /širina $\mu>3$ ) ili izometričnog oblika $(\mu<3)$, ovisno o geometriji rezanja i smjeru rezanja s obzirom na vlakanca.

Utjecajni čimbenik katkad može biti i oblik rezne oštrice. Naime, istraživanje Očkajove i dr. (2006.) pokazalo je da pri piljenju smrekovine, bukovine i merantija listom sa stlačenim zubima nastaju krupnije čestice usitnjenog materijala te da je u smjesi dvostruko manje čestica sitnijih od $1 \mathrm{~mm}$ nego pri piljenju listom pile s asimetričnim trobridnim razvraćenim zubima.

U tablici 1. dane su vrijednosti faktora rastresitosti različitoga usitnjenog materijala iz dosadašnje lite- 
Tablica 1. Faktor rastresitosti sipkog materijala (Sever, 1988.)

Table 1 Looseness factor of chipped material (Sever, 1988)

\begin{tabular}{|l|c|}
\hline $\begin{array}{l}\text { Vrsta sipkog materijala } \\
\text { Type of chipped material }\end{array}$ & $\begin{array}{c}\text { Faktor rastresitosti }\left(f_{\mathrm{r}}\right) \\
\text { Looseness factor }\left(f_{\mathrm{r}}\right)\end{array}$ \\
\hline $\begin{array}{l}\text { iverje s piljevinom } \\
\text { chips with sawdust }\end{array}$ & 2,65 \\
\hline iverje / chips & 3 \\
\hline piljevina / sawdust & 3,2 \\
\hline blanjevina / shavings & 4,6 \\
\hline
\end{tabular}
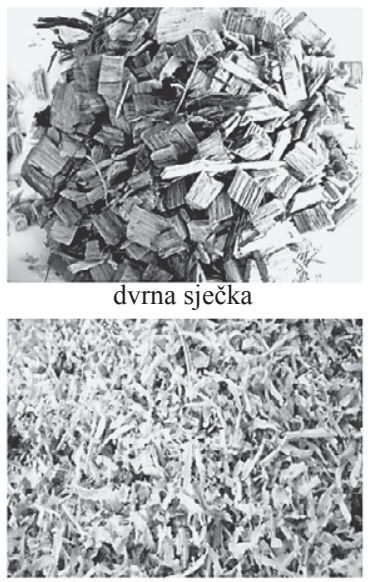

blanjevina

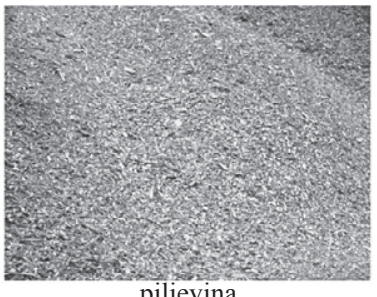

piljevina

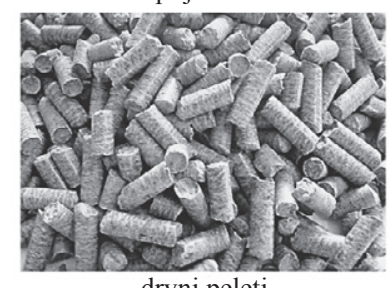

drvni peleti
Slika 1. Vrste sipkoga drvnog materijala

Figure 1 Type of chipped wood material

rature (Sever, 1988.), a na slici 1. prikazane su neke vrste sipkoga drvnog materijala u drvoprerađivačkoj industriji.

Posljedica povećanja volumena usitnjenog drva jest smanjenje njegove nasipne gustoće s obzirom na gustoću cjelovitog drva. Nasipna gustoća $(\rho)$ definira se kao masa jedinice volumena nasutog materijala $(\mathrm{kg} /$ $\mathrm{dm}^{3} ; \mathrm{kg} / \mathrm{m}^{3} \mathrm{i} \mathrm{dr}$.). Određuje se uz pomoć mjerne posude poznatog volumena $\left(1-3 \mathrm{dm}^{3}\right)$. Materijal može biti slobodno nasut $(\rho)$ ili stlačen $\left(\rho_{\mathrm{s}}\right)$. Omjer tih dviju gustoća $\psi=\rho_{\mathrm{s}} / \rho$ daje stupanj stlačenja (Madjarević, 1969.). Ovisno o stupnju stlačenja (zbijenosti) te granulometrijskom sastavu i sadržaju vode u drvu stlačivanjem je moguće postići neznatno povećanje nasipne gustoće. Time se omogućuje povećanje nasipne gustoće suhoga zrnatog materijala za 5 do $10 \%$, dok je stlačivanjem vlažnog materijala moguće povećanje nasipne gustoće za 30 do $50 \%$.

$\mathrm{S}$ obzirom na nasipnu gustoću, razlikuju se ovi sipki materijali: laki, nasipne gustoće do $0,6 \mathrm{t} / \mathrm{m}^{3}$ (drvna piljevina, koks); srednje teški, nasipne gustoće od 0,6 do $1,1 \mathrm{t} / \mathrm{m}^{3}$ (kameni ugljen, šljaka) i vrlo teški, nasipne gustoće veće od 2 t/m³ (rude) (Sever, 1988.).

Usitnjeni materijali nastali na tračnoj pili, brusilici i bušilici pripadaju skupini materijala veće nasipne gustoće. U skupini materijala manje nasipne gustoće nalaze se materijali nastali obradom na kružnoj pili i blanjalici (Beljo Lučić i dr., 2005.).

Odnos između nasipne gustoće piljevine (označene indeksom 1) i drugih vrsta drvnih ostataka jednakog sadržaja vode za blanjevinu iznosi 0,69; za blanje-
Tablica 2. Nasipna gustoća usitnjenog materijala za različite vrste drva i različit sadržaj vode u njemu (Madjarević, 1969.) Table 2 Bulk density of chipped material for different wood species and moisture content (Madjarević, 1969)

\begin{tabular}{|c|c|c|c|}
\hline \multirow{2}{*}{$\begin{array}{c}\text { Sadržaj vode u } \\
\text { drvu, \% } \\
\begin{array}{c}\text { Moisture } \\
\text { content, } \%\end{array}\end{array}$} & \multicolumn{3}{|c|}{$\begin{array}{c}\text { Nasipna gustoća, } \mathrm{kg} / \mathrm{m}^{3} \\
\text { Bulk density, } \mathrm{kg} / \mathrm{m}^{3}\end{array}$} \\
\cline { 2 - 4 } & $\begin{array}{c}\text { Jelovina } \\
\text { fir-wood }\end{array}$ & $\begin{array}{c}\text { Bukovina } \\
\text { beech-wood }\end{array}$ & $\begin{array}{c}\text { hrastovina } \\
\text { oak-wood }\end{array}$ \\
\hline 10 & 140 & 206 & 225 \\
\hline 25 & 152 & 220 & 240 \\
\hline 50 & 180 & 259 & 283 \\
\hline 75 & 210 & 305 & 330 \\
\hline 100 & 240 & 346 & 420 \\
\hline
\end{tabular}

vinu i iverje 1,1; za iverje 1,05, a za iverje i piljevinu 1,2 (Sever, 1988.).

U tablici 2. navedeni su podaci iz literature (Madjarević, 1969.) za nasipne gustoće usitnjenog materijala istraživanih vrsta drva različitog sadržaja vode.

U dosadašnjim istraživanjima faktor rastresitosti usitnjenoga drvnog materijala nije temeljito analiziran niti o tome postoje opširniji podaci u literaturi. Rezultati ovog istraživanja pridonijet će upoznavanju faktora rastresitosti i nasipne gustoće usitnjenog materijala dobivenog od triju vrsta drva pri različitim uvjetima blanjanja. Cilj rada bio je ustanoviti imaju li posmična brzina, prednji kut oštrice i vrsta drva značajan utjecaj na faktor rastresitosti usitnjenog materijala nastaloga pri blanjanju drva.

\section{MATERIJALI I METODE \\ 2 MATERIALS AND METHODS}

Odabrani su uzorci radijalnog smjera vlakanaca (blistače) triju vrsta drva - jelovine, hrastovine i bukovine (parena bukovina i termički modificirana bukovina pri temperaturi $212^{\circ} \mathrm{C}$; dalje u tablicama i grafovima: bukovina $212^{\circ} \mathrm{C}$ ).

Uzorci dimenzija $600 \times 70 \times 21 \mathrm{~mm}$ blanjani su na viševretenoj blanjalici (WEINIG Powermat 400, 2006.). Obrađivana je samo jedna, donja, strana uzorka uz visinu blanjanja $\Delta h=2 \mathrm{~mm}$ i promjenu posmičnih brzina kako slijedi: $v_{\mathrm{p} 1}=6 ; v_{\mathrm{p} 2}=12 ; v_{\mathrm{p} 3}=18$ i $v_{\mathrm{p} 4}=24$ $\mathrm{m} / \mathrm{min}$. Broj okretaja radne glave iznosio je $6000 \mathrm{~min}^{-1}$. Blanjanje je provedeno konvencionalnom glavom za blanjanje s dva noža kojima su mijenjani prednji kutovi oštrice kako slijedi: $\gamma_{1}=15^{\circ} ; \gamma_{2}=20^{\circ} \mathrm{i} \gamma_{3}=25^{\circ}$ (sl. 3.).

$\mathrm{Za}$ crtanje srednje debljine strugotine, duljine luka zahvata, posmaka po zubu i bočne površine strugotine primijenjen je program AutoCAD 2007 (sl. 4.). Vrijednosti izmjerene na taj način (tabl. 4.) provjerene su računskim postupkom i ne razlikuju se značajno od izračunanih vrijednosti. Slika 4. prikazuje glavu s nožem u zahvatu i mjerene veličine značajne za faktor rastresitosti i nasipnu gustoću usitnjenog materijala.

Nakon blanjanja svakoga od 48 uzoraka blanjevina je prikupljena u PVC vrećicu kako vanjska temperatura i vlaga ne bi utjecale na suhi materijal. Volumen rastresitog materijala određen je uz pomoć menzure od $2000 \mathrm{ml} \mathrm{u}$ koju je nasipavan s visine od $100 \mathrm{~mm} \mathrm{kroz}$ lijevak. 


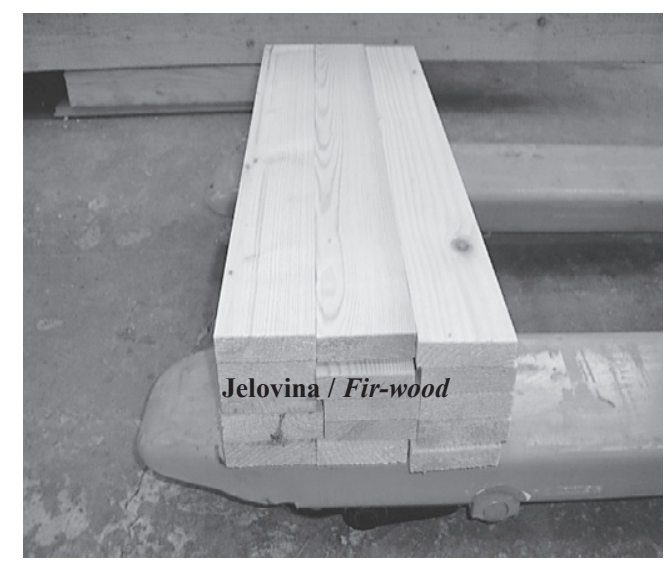

Slika 2. Uzorci odabranih vrsta drva

Figure 2 Samples of selected wood species

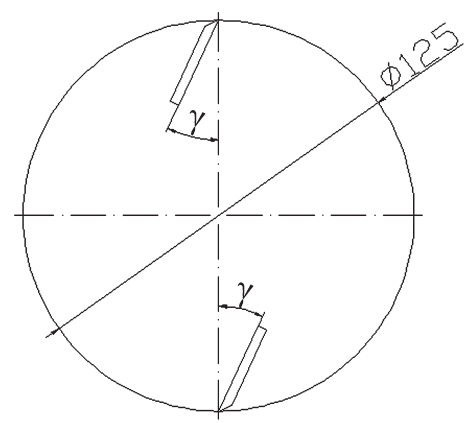

Slika 3. Radna glava s nožem prednjeg kuta oštrice $\gamma$ Figure 3 Cutting tool with rake angle $\gamma$

Iz poznatih dimenzija uzorka i visine blanjanja uz pomoć izraza (1) izračunan je volumen kompaktnog $\operatorname{drva}\left(V_{\mathrm{k}}\right)$ :

$$
V_{\mathrm{k}}=L \cdot B \cdot \Delta h
$$

gdje je:

$L$ - duljina uzorka, mm

$B$ - širina uzorka, $\mathrm{mm}$

$\Delta h$ - dodatak za obradu, $\mathrm{mm}$.

Faktor rastresitosti usitnjenog materijala $\left(f_{\mathrm{r}}\right)$ izračunan je kao omjer volumena usitnjenog materijala $i$ volumena kompaktnog drva:

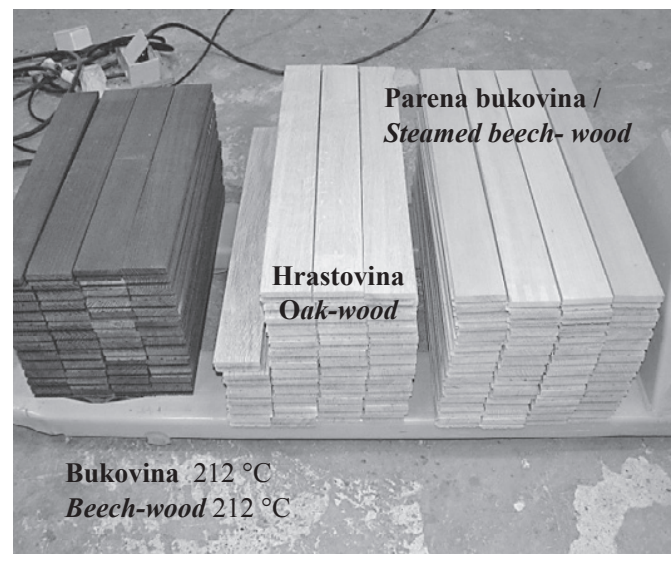

$$
f_{\mathrm{r}}=\frac{V_{\mathrm{r}}}{V_{\mathrm{k}}}
$$

gdje je:

$V_{\mathrm{r}}-$ volumen usitnjenog materijala, $\mathrm{dm}^{3}$

$V_{\mathrm{k}}^{\mathrm{r}}$ - volumen kompaktnog drva, $\mathrm{dm}^{3}$.

Faktor rastresitosti određen je i iz omjera gustoće kompaktnog drva i nasipne gustoće usitnjenog materijala:

gdje je:

$$
f_{\mathrm{r}}=\frac{\rho_{\mathrm{k}}}{\rho_{\mathrm{r}}}
$$

$\rho_{\mathrm{k}}$ - gustoća kompaktnog drva, $\mathrm{kg} / \mathrm{m}^{3}$

$\rho_{\mathrm{r}}$ - nasipna gustoća usitnjenog materijala, $\mathrm{kg} / \mathrm{m}^{3}$.

Nasipna gustoća usitnjenog materijala $\left(\rho_{\mathrm{r}}\right)$ određena je vaganjem menzure poznatog volumena (800 $\mathrm{ml}$ ) prije i nakon nasipavanja usitnjenog materijala uz pet ponavljanja. Iz razlike tih dviju masa dobivena je masa usitnjenog materijala, a nasipna je gustoća izračunana prema izrazu (4):

$$
\rho_{\mathrm{r}}=\frac{m}{V}
$$

gdje je:

$m$ - masa usitnjenog materijala, $\mathrm{kg}$

$V$ - volumen usitnjenog materijala $\left(\mathrm{V}=800 \mathrm{ml} ; \mathrm{dm}^{3}\right)$.

Gustoća u apsolutno suhom stanju određena je gravimetrijskom metodom, a gustoća pri izmjerenom sadržaju vode dobivena je iz izraza (5), koji vrijedi

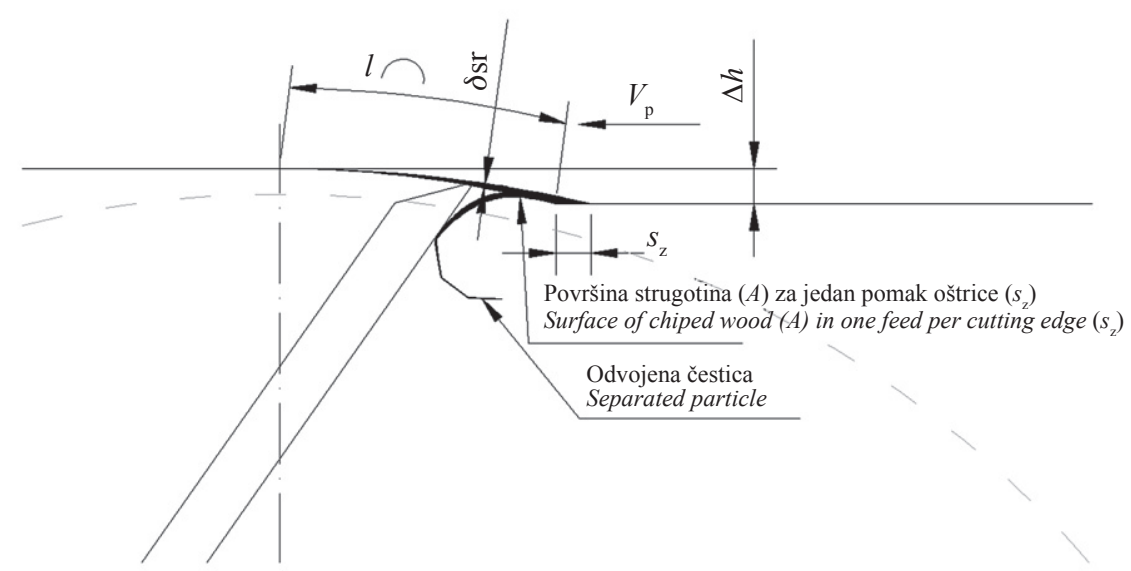

Slika 4. Veličine geometrije reza

Figure 4 Geometrical values of cut 
samo za područje od 0 do $25 \%$ sadržaja vode u drvu. Sadržaj vode uzoraka izmjeren je klasičnim igličnim vlagomjerom GANN, model HT 85T (GANN, 2006.), prema normi EN 13183-2:2008, a gustoća pri određenom sadržaju vode izračunana je prema izrazu:

$$
\rho_{\mathrm{w}}=\rho_{0} \cdot \frac{1+w}{1+0,84 \cdot \rho_{0} \cdot w}
$$

gdje je:

$\rho_{\mathrm{w}}-$ gustoća pri određenom sadržaju vode, $\mathrm{g} / \mathrm{cm}^{3}$

$\rho_{0}$ - gustoća u apsolutno suhom stanju, $\mathrm{g} / \mathrm{cm}^{3}$

$w$ - sadržaj vode, $\%$.

Statistička razlika između faktora rastresitosti uzoraka dobivenih pri različitim uvjetima blanjanja testirana je Studentovim $t$-testom. U slučaju nehomogenosti varijanci poslužila je neparametarska analiza Mann-Whitneyjevim $u$-testom (McClave i Dietrich, 1988.). Statističke analize rađene su primjenom statističkog programa STATISTICA 6.0.

\section{REZULTATI I DISKUSIJA 3 RESULTS AND DISCUSSION}

U tablici 3. prikazane su vrijednosti sadržaja vode i gustoće uzoraka drva pri navedenom sadržaju vode te gustoće drva u apsolutno suhom stanju za različite vrste drva.
U tablici 4. navedene su izmjerene vrijednosti posmaka po nožu, srednje debljine strugotine, duljine luka zahvata i bočne površine strugotine za različite posmične brzine $\left(v_{\mathrm{p}}\right)$.

U tablicu 5. uvrštene su vrijednosti faktora rastresitosti $f_{\mathrm{r}}$ dobivene iz omjera volumena usitnjenog materijala $\left(V_{\mathrm{r}}\right)$ i kompaktnog drva $\left(V_{\mathrm{k}}\right)$ za različite posmične brzine i prednje kutove oštrice.

Prema teoriji rezanja moglo bi se očekivati da će s povećanjem posmične brzine nastati usitnjeni materijal s većim česticama i manjom nasipnom gustoćom odnosno s većim faktorom rastresitosti. Ipak, rezultati istraživanja pokazali su kako se za većinu uzoraka s povećanjem posmične brzine nasipna gustoća povećala odnosno faktor rastresitosti blanjevine smanjio (tabl. 5. i 6.). I ovim je istraživanjem potvrđen manji utjecaj posmične brzine odnosno debljine strugotine na usitnjenost materijala, a značajnim čimbenikom pokazao se smjer rezanja s obzirom na smjer vlakanaca (Beljo Lučić i dr., 2007b). Pri istosmjernom rezanju veća je vjerojatnost pojave sitnijih frakcija čestica.

U usporedbi s podacima iz literature (Madjarević, 1969.), dobivene su nasipne gustoće (tabl. 6.) i do pet puta manje za jelovinu te do tri puta manje za hrastovinu, ovisno o uvjetima nastanka usitnjenog materijala.

U tablici 7. dane su vrijednosti faktora rastresitosti usitnjenog materijala dobivenoga iz omjera gustoće

Tablica 3. Sadržaj vode i gustoća uzoraka

Table 3 Moisture content and density of samples

\begin{tabular}{|l|c|c|c|}
\hline \multicolumn{1}{|c|}{$\begin{array}{c}\text { Vrsta drva } \\
\text { Wood species }\end{array}$} & $\begin{array}{c}\text { Sadržaj vode, \% } \\
\text { Moisture content, \% }\end{array}$ & $\begin{array}{c}\text { Gustoća, } \mathbf{~ k g} / \mathbf{m}^{3} \\
\text { Density, } \mathrm{kg} / \mathrm{m}^{3}\end{array}$ & $\begin{array}{c}\text { Gustoća u aps. suhom stanju, } \mathbf{~ k g} / \mathbf{m}^{3} \\
\text { Density in dry condition, } \mathrm{kg} / \mathrm{m}^{3}\end{array}$ \\
\hline jelovina / fir-wood & 18,27 & 481,24 & 434 \\
\hline hrastovina / oak-wood & 9,31 & 682,08 & 656 \\
\hline $\begin{array}{l}\text { parena bukovina } \\
\text { steamed beech-wood }\end{array}$ & 9,18 & 689,64 & 664 \\
\hline $\begin{array}{l}\text { bukovina } 212{ }^{\circ} \mathrm{C} \\
\text { beech-wood } 212{ }^{\circ} \mathrm{C}\end{array}$ & 4,47 & 676,81 & 639 \\
\hline
\end{tabular}

Tablica 4. Vrijednosti geometrije reza određene uz pomoć programa AutoCAD za različite posmične brzine odnosno posmake po zubu

Table 4 Values of cutting geometry obtained using AutoCAD for different feed speeds and feed rates

\begin{tabular}{|c|c|c|c|c|}
\hline $\begin{array}{c}\text { Posmična brzina } \\
\text { Feed speed }\end{array}$ & $\begin{array}{c}\text { Posmak po zubu } \\
\text { Feed rate }\end{array}$ & $\begin{array}{c}\text { Duljina luka zahvata } \\
\text { Length of cut }\end{array}$ & $\begin{array}{c}\text { Debljina strugotine } \\
\text { Chip thickness }\end{array}$ & $\begin{array}{c}\text { Bočna površina strugotine } \\
\text { Side surface of chip }\end{array}$ \\
\hline $\mathrm{m} / \mathrm{min}$ & $\mathrm{mm}$ & $\mathrm{mm}$ & $\mathrm{mm}$ & $\mathrm{mm}^{2}$ \\
\hline 6 & 0,5 & 16,31 & 0,063 & 0,999 \\
\hline 12 & 1 & 16,85 & 0,13 & 1,999 \\
\hline 18 & 1,5 & 17,35 & 0,19 & 2,998 \\
\hline 24 & 2 & 17,85 & 0,24 & 3,995 \\
\hline
\end{tabular}

Tablica 5. Faktor rastresitosti $\left(V_{\mathrm{r}} / V_{\mathrm{k}}\right)$ za različite vrste drva pri odabranoj posmičnoj brzini $\left(v_{\mathrm{p}}\right)$ i prednjem kutu oštrice $(\gamma)$ Table 5 Looseness factor $\left(V_{\mathrm{r}} / V_{\mathrm{k}}\right)$ for different wood species at selected feed speed $\left(v_{\mathrm{p}}\right)$ and rake angle $(\gamma)$

\begin{tabular}{|c|c|c|c|c|c|c|c|c|c|c|c|c|}
\hline \multirow{4}{*}{$\begin{array}{c}\text { Vrsta drva } \\
\text { Wood species }\end{array}$} & \multicolumn{4}{|c|}{$\begin{array}{l}\text { Prednji kut } \mathbf{1 5}^{\circ} \\
\text { Rake angle } 15^{\circ}\end{array}$} & \multicolumn{4}{|c|}{$\begin{array}{c}\text { Prednji kut } \mathbf{2 0}^{\circ} \\
\text { Rake angle } 20^{\circ}\end{array}$} & \multicolumn{4}{|c|}{$\begin{array}{l}\text { Prednji kut } \mathbf{2 5}^{\circ} \\
\text { Rake angle } 25^{\circ}\end{array}$} \\
\hline & \multicolumn{4}{|c|}{$v_{\mathrm{p},} \mathrm{m} / \mathrm{min}$} & \multicolumn{4}{|c|}{$v_{\mathrm{p},} \mathrm{m} / \mathrm{min}$} & \multicolumn{4}{|c|}{$v_{\mathrm{p},} \mathrm{m} / \mathrm{min}$} \\
\hline & 6 & 12 & 18 & 24 & 6 & 12 & 18 & 24 & 6 & 12 & 18 & 24 \\
\hline & \multicolumn{12}{|c|}{ Faktor rastresitosti, $f_{\mathrm{r}}\left(V_{\mathrm{r}} / V_{\mathrm{k}}\right) /$ Looseness factor, $f_{\mathrm{r}}\left(V_{\mathrm{r}} / V_{\mathrm{k}}\right)$} \\
\hline jelovina / fir-wood & 28 & 22 & 16 & 99 & 18 & 15 & 11 & 11 & 22 & 15 & 12 & 10 \\
\hline hrastovina / oak-wood & 9 & 6 & 6 & 5 & 7 & 6 & 5 & 4 & 5 & 5 & 5 & 8 \\
\hline parena bukovina / steamed beech-wood & 16 & 12 & 10 & 8 & 18 & 11 & 9 & 8 & 15 & 10 & 9 & 11 \\
\hline bukovina $212^{\circ} \mathrm{C} /$ beech-wood $212^{\circ} \mathrm{C}$ & 4 & 3 & 4 & 3 & 3 & 3 & 3 & 4 & 3 & 4 & 3 & 4 \\
\hline
\end{tabular}


Tablica 6. Srednja vrijednost nasipne gustoće $\left(\rho_{\mathrm{r}}\right)$ za različite vrste drva pri odabranoj posmičnoj brzini $\left(v_{\mathrm{p}}\right)$ i prednjem kutu oštrice $(\gamma)$

Table 6 Arithmetic mean values of bulk density $\left(\rho_{\mathrm{r}}\right)$ for different wood species at selected feed speed $\left(v_{\mathrm{p}}\right)$ and rake angle $(\gamma)$

\begin{tabular}{|c|c|c|c|c|c|c|c|c|c|c|c|c|}
\hline \multirow{4}{*}{$\begin{array}{c}\text { Vrsta drva } \\
\text { Wood species }\end{array}$} & \multicolumn{4}{|c|}{$\begin{array}{l}\text { Prednji kut } \mathbf{1 5}^{\circ} \\
\text { Rake angle } 15^{\circ}\end{array}$} & \multicolumn{4}{|c|}{$\begin{array}{l}\text { Prednji kut } \mathbf{2 0}^{\circ} \\
\text { Rake angle } 20^{\circ}\end{array}$} & \multicolumn{4}{|c|}{$\begin{array}{l}\text { Prednji kut } 25^{\circ} \\
\text { Rake angle } 25^{\circ}\end{array}$} \\
\hline & \multicolumn{4}{|c|}{$v_{\mathrm{p}, \mathrm{m} / \mathrm{min}}$} & \multicolumn{4}{|c|}{$v_{\mathrm{p},} \mathrm{m} / \mathrm{min}$} & \multicolumn{4}{|c|}{$v_{\mathrm{p},} \mathrm{m} / \mathrm{min}$} \\
\hline & 6 & 12 & 18 & 24 & 6 & 12 & 18 & 24 & 6 & 12 & 18 & 24 \\
\hline & \multicolumn{12}{|c|}{ Srednja vrijednost nasipne gustoće, $\rho_{\mathrm{r}}, \mathrm{kg} / \mathrm{m}^{3} /$ Arithmetic mean values of bulk density, $\rho_{\mathrm{r}^{2}}, \mathrm{~kg} / \mathrm{m}^{3}$} \\
\hline jelovina / fir-wood & 31,01 & 48,24 & 50,09 & 55,89 & 29,87 & 41,86 & 59,48 & 63,51 & 25,97 & 42,93 & 45,9 & 53,55 \\
\hline $\begin{array}{l}\text { hrastovina } \\
\text { oak-wood }\end{array}$ & 66,00 & 122,37 & 128,45 & 166,48 & 98,88 & 127,21 & 159,63 & 173,57 & 141,69 & 146,47 & 183,36 & 189,55 \\
\hline $\begin{array}{l}\text { parena bukovina } \\
\text { steamed } \\
\text { beech-wood }\end{array}$ & 41,22 & 62,38 & 79,24 & 98,36 & 44,96 & 73,14 & 92,04 & 99,93 & 58,97 & 82,8 & 95,87 & 88,91 \\
\hline $\begin{array}{l}\text { bukovina } 212{ }^{\circ} \mathrm{C} \\
\text { beech-wood } 212^{\circ} \mathrm{C}\end{array}$ & 112,33 & 144,87 & 160,16 & 191,73 & 159,69 & 160,03 & 189,98 & 185,26 & 167,49 & 168,74 & 185,23 & 192,49 \\
\hline
\end{tabular}

kompaktnog drva i nasipne gustoće usitnjenog materijala. Faktori rastresitosti dobiveni na taj način približno su jednaki onima koji su izračunani kao omjer volumena usitnjenog materijala i volumena kompaktnog drva. Međutim, ovisno o vrsti drva, faktori rastresitosti za blanjevinu višestruko su veći od vrijednosti u postojećoj literaturi (Sever, 1988.), u kojoj je to samo 4,6.

\subsection{Utjecaj posmične brzine na faktor rastresitosti} 3.1 Influence of feed speed on looseness factor

Na slikama 5., 6. i 7. za svaki od odabranih prednjih kutova oštrice dijagramom je prikazan utjecaj posmične brzine na promjenu prosječne vrijednosti faktora rastresitosti dobivenih iz omjera volumena usitnjenog materijala i volumena kompaktnog drva $\left(V_{\mathrm{r}} / V_{\mathrm{k}}\right)$.

Kako prikazuju dijagrami, vidljive su značajne promjene faktora rastresitosti usitnjenog materijala jelovine i bukovine za raspon posmične brzine između 6 i $24 \mathrm{~m} / \mathrm{min}$. Najveće smanjenje faktora rastresitosti za sve prednje kutove oštrice i uz povećanje posmične brzine zabilježeno je pri obradi parene bukovine, dok promjena nije zabilježena za uzorke hrastovine ni za termički modificiranu bukovinu.

Usporedbom srednjih vrijednosti faktora rastresitosti prikazanih na slikama 9., 10. i 11. za uzorke jelovine postoji statistički značajna razlika za sve skupine uzoraka $(p=0)$. Ta razlika nije dokazana za uzorke nastale pri piljenju posmičnom brzinom od 12 i $18 \mathrm{~m} /$ min pri najmanjem prednjem kutu oštrice $\gamma_{1}(p=0,38)$ te za uzorke nastale piljenjem uz posmičnu brzinu $12 \mathrm{i}$ $18 \mathrm{~m} / \mathrm{min}$ i najveći prednji kut oštrice $\gamma_{3}(p=0,12)$. Također nije utvrđena statistički značajna razlika između faktora rastresitosti za termički modificirane uzorke nastale pri posmičnoj brzini od 6 i $12 \mathrm{~m} / \mathrm{min}$ za prednji kut oštrice $\gamma_{2}(p=0,88)$ i posmičnu brzinu $18 \mathrm{i}$ $24 \mathrm{~m} / \mathrm{min}(p=0,07)$. Isto vrijedi $(p=0,18)$ za uzorke nastale blanjanjem uz posmičnu brzinu 6 i $12 \mathrm{~m} / \mathrm{min}$ i prednji kut oštrice $\gamma_{3}$.

\subsection{Utjecaj prednjeg kuta oštrice na faktor rastresitosti}

3.2 Influence of rake angle on looseness factor

Statistički su testovi pokazali da ne postoji signifikantna razlika između faktora rastresitosti blanjevine nastale obradom jelovine pri najmanjoj posmičnoj brzini za kutove $\gamma_{1} \mathrm{i} \gamma_{2}(p=0,24)$. Isto se može reći i za blanjevinu nastalu pri posmičnoj brzini od $12 \mathrm{~m} / \mathrm{min} \mathrm{s}$ prednjim kutom oštrice $\gamma_{2}$ i $\gamma_{3}(p=0,41)$. Blanjevina jelovine nastala pri posmičnoj brzini od $18 \mathrm{~m} / \mathrm{min}$ ima isti faktor rastresitosti pri obradi drva uz najmanji $\gamma_{1} \mathrm{i}$ najveći $\gamma_{3}$ prednji kut oštrice $(p=0,09)$. Pri blanjanju uzoraka hrastovine za sve skupine uzoraka postoji statistički značajna razlika $\mathrm{u}$ faktoru rastresitosti $\mathrm{s}$ obzirom na prednji kut oštrice $(p=0)$. Za uzorke blanjevine parene bukovine utvrđena je statistički značajna razlika između faktora rastresitosti svih skupina uzoraka s obzirom na prednji kut oštrice $(p=0)$. To ne vrijedi za uzorke nastale blanjanjem kad je oštrica imala

Tablica 7. Faktor rastresitosti $\left(\rho_{\mathrm{k}} / \rho_{\mathrm{r}}\right)$ za različite vrste drva pri odabranoj posmičnoj brzini $\left(v_{\mathrm{p}}\right)$ i prednjem kutu oštrice $(\gamma)$ Table 7 Looseness factor $\left(\rho_{\mathrm{k}} / \rho_{\mathrm{r}}\right)$ for different wood species at selected feed speed $\left(v_{\mathrm{p}}\right)$ and rake angle $(\gamma)$

\begin{tabular}{|c|c|c|c|c|c|c|c|c|c|c|c|c|}
\hline \multirow{4}{*}{$\begin{array}{c}\text { Vrsta drva } \\
\text { Wood species }\end{array}$} & \multicolumn{4}{|c|}{$\begin{array}{l}\text { Prednji kut } \mathbf{1 5}^{\circ} \\
\text { Rake angle } 15^{\circ}\end{array}$} & \multicolumn{4}{|c|}{$\begin{array}{l}\text { Prednji kut } \mathbf{2 0}^{\circ} \\
\text { Rake angle } 20^{\circ}\end{array}$} & \multicolumn{4}{|c|}{$\begin{array}{l}\text { Prednji kut } 25^{\circ} \\
\text { Rake angle } 25^{\circ}\end{array}$} \\
\hline & \multicolumn{4}{|c|}{$v_{\mathrm{p}}, \mathrm{m} / \mathrm{min}$} & \multicolumn{4}{|c|}{$v_{\mathrm{p}}, \mathrm{m} / \mathrm{min}$} & \multicolumn{4}{|c|}{$v_{\mathrm{p}}, \mathrm{m} / \mathrm{min}$} \\
\hline & 6 & 12 & 18 & 24 & 6 & 12 & 18 & 24 & 6 & 12 & 18 & 24 \\
\hline & \multicolumn{12}{|c|}{ Faktor rastresitosti, $f_{\mathrm{r}}\left(\rho_{\mathrm{k}} / \rho_{\mathrm{r}}\right) /$ Looseness factor, $f_{\mathrm{r}}\left(\rho_{\mathrm{k}} / \rho_{\mathrm{r}}\right)$} \\
\hline jelovina / fir-wood & 15,52 & 9,98 & 9,61 & 8,61 & 16,11 & 11,50 & 8,09 & 7,58 & 18,53 & 11,21 & 10,49 & 8,99 \\
\hline hrastovina / oak-wood & 10,33 & 5,57 & 5,31 & 4,10 & 6,90 & 5,36 & 4,27 & 3,93 & 4,81 & 4,66 & 3,72 & 3,60 \\
\hline $\begin{array}{l}\text { parena bukovina / steamed } \\
\text { beech-wood }\end{array}$ & 16,73 & 11,06 & 8,70 & 7,01 & 15,34 & 9,43 & 7,49 & 6,90 & 11,70 & 8,33 & 7,19 & 7,76 \\
\hline $\begin{array}{l}\text { bukovina } 212{ }^{\circ} \mathrm{C} \\
\text { beech-wood } 212^{\circ} \mathrm{C}\end{array}$ & 6,03 & 4,67 & 4,23 & 3,53 & 4,24 & 4,23 & 3,56 & 3,65 & 4,04 & 4,01 & 3,65 & 3,52 \\
\hline
\end{tabular}




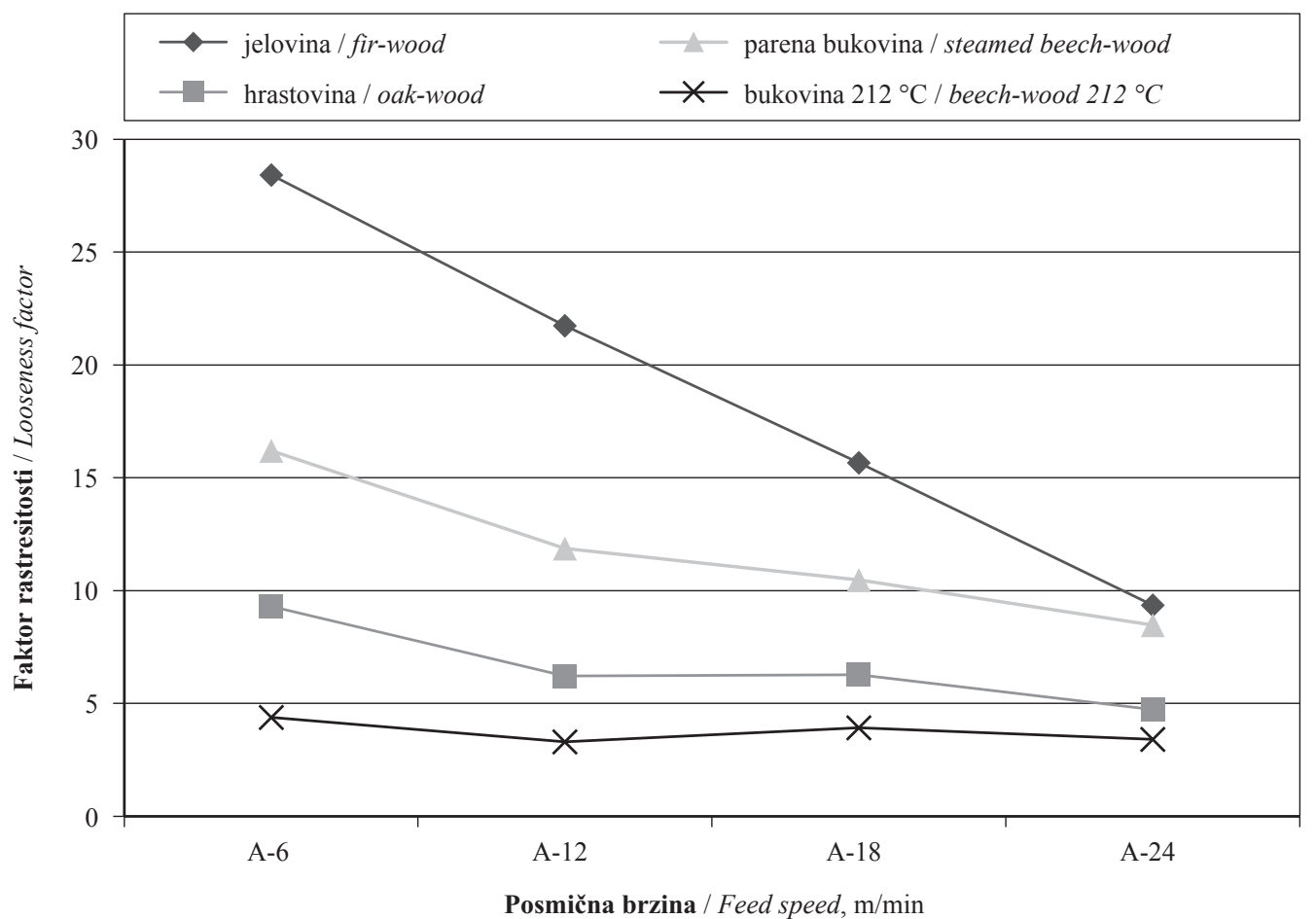

Slika 5. Faktor rastresitosti $\left(V_{\mathrm{r}} / V_{\mathrm{k}}\right)$ za prednji kut oštrice $\gamma_{1}=15^{\circ}$ (A)

Figure 5 Looseness factor $\left(V_{\mathrm{r}} / V_{\mathrm{k}}\right)$ at rake angle $\gamma_{1}=15^{\circ}(\mathrm{A})$

prednji kut $\gamma_{1}$ i $\gamma_{2}$, pa je faktor rastresitosti bio jednak ( $p$ $=0,37$ ) pri posmičnoj brzini od $24 / \mathrm{min}$. Nema statistički značajne razlike ni među faktorima rastresitosti uzoraka blanjevine termički modificirane bukovine nastale pri posmičnoj brzini od $24 \mathrm{~m} / \mathrm{min}$ pri najmanjem prednjem kutu oštrice $\gamma_{1}$ i onih dobivenih pri najvećem $\gamma_{3}$ prednjem kutu oštrice $(p=0,62)$. Za sve ostale skupine uzoraka termički modificirane bukovine postoji statistički značajna razlika među faktorima rastresitosti $(p=0)$. Usporedba srednjih vrijednosti faktora rastresitosti za sve skupine uzoraka prikazana je na slikama 9., 10. i 11.

Granulometrijska analiza prijašnjih istraživanja na istim uzorcima pokazala je da pri blanjanju termički modificirane bukovine, ako se blanja alatom koji ima veći prednji kut, i pri malim posmičnim brzinama nastaje

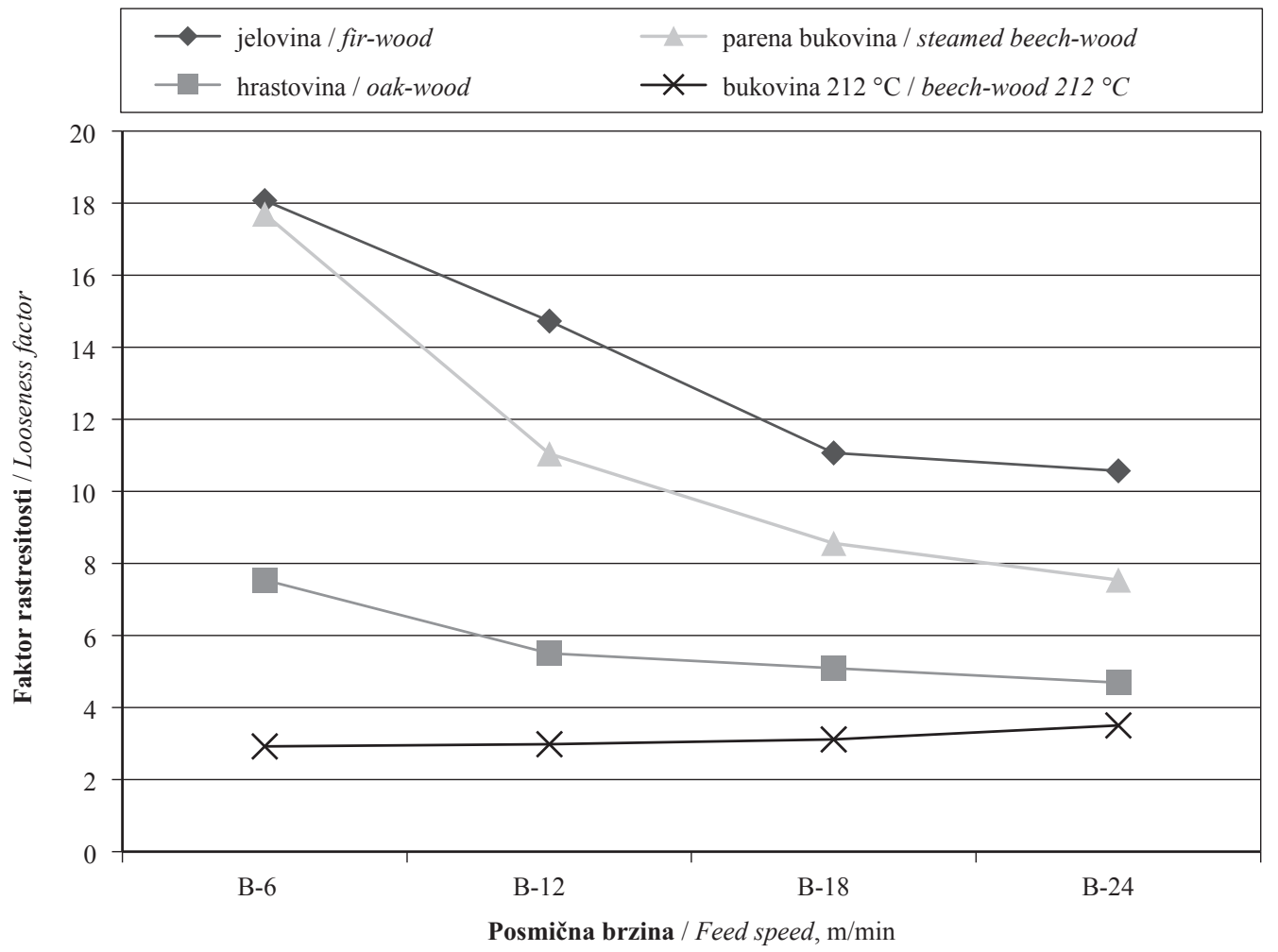

Slika 6. Faktor rastresitosti $\left(V_{\mathrm{r}} / V_{\mathrm{k}}\right)$ za prednji kut oštrice $\gamma_{2}=20^{\circ}$ (B)

Figure 6 Looseness factor $\left(V_{\mathrm{r}}^{\mathrm{r}} / V_{\mathrm{k}}\right)$ at rake angle $\gamma_{2}=20^{\circ}(\mathrm{B})$ 


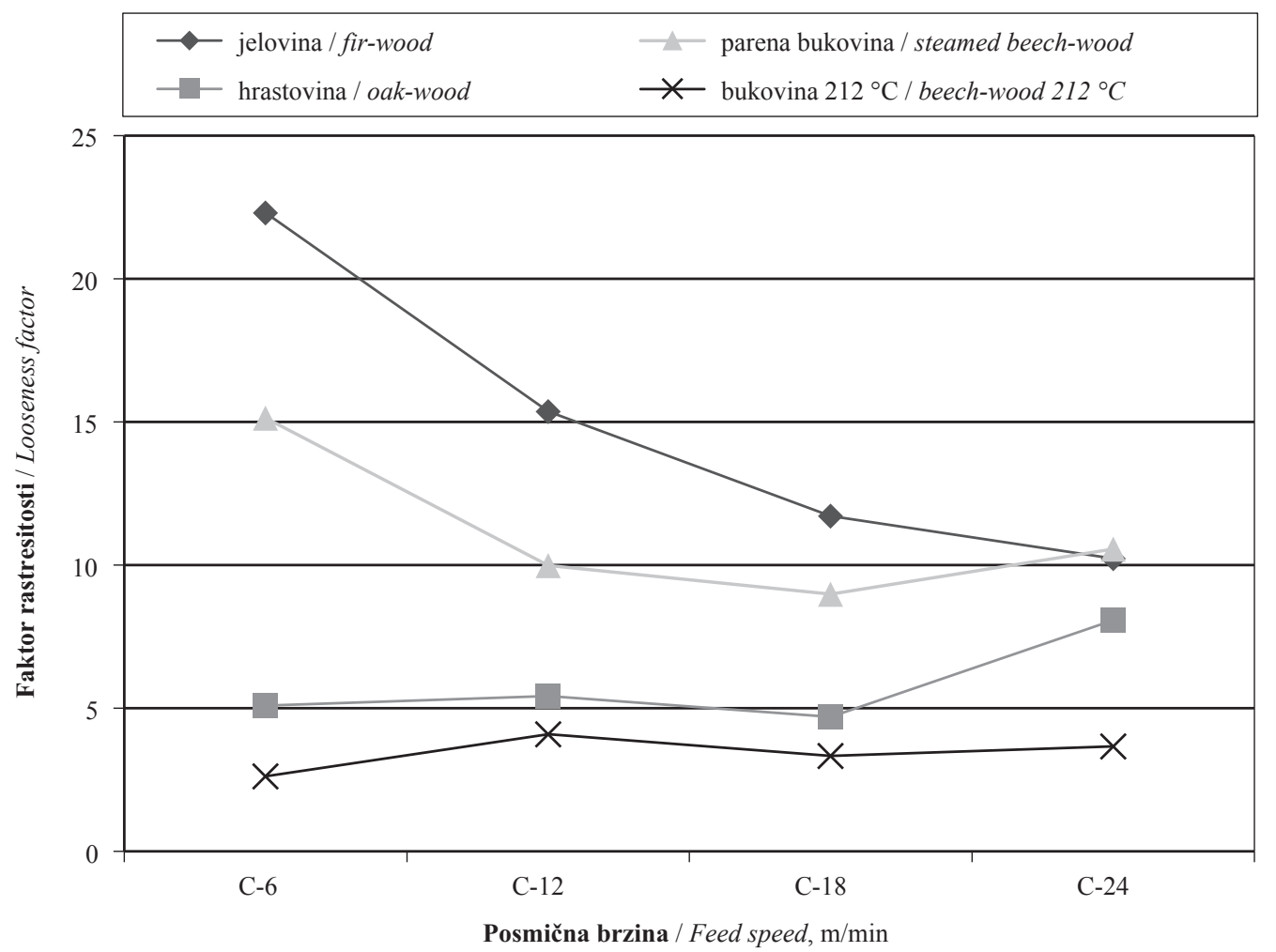

Slika 7. Faktor rastresitosti $\left(V_{\mathrm{r}} / V_{\mathrm{k}}\right)$ za prednji kut oštrice $\gamma_{3}=25^{\circ}(\mathrm{C})$

Figure 7 Looseness factor $\left(V_{\mathrm{r}} / V_{\mathrm{k}}\right)$ at rake angle $\gamma_{3}=25^{\circ}(\mathrm{C})$

više sitnijih čestica. Za uzorke parene bukovine pri velikim je posmičnim brzinama rezultat povećanja prednjeg kuta blanjanja suprotan, to jest nastaju krupnije čestice (Beljo Lučić i dr., 2009.). Istraživanja Palmqvista i Gustafssona (1999.) također nisu pokazala nedvojben utjecaj prsnog kuta oštrice $\left(0-30^{\circ}\right)$ na usitnjavanje materijala pri blanjanju borovine, bukovine i MDF-a.

\subsection{Utjecaj vrste drva na faktor rastresitosti}

3.3 Influence of wood species on looseness factor

Usporedba faktora rastresitosti blanjevine odabranih vrsta drva, posmičnih brzina i prednjih kutova prikazana je na slici 8., a statistička usporedba srednjih vrijednosti predočena je slikama 9., 10. i 11. Najveća razlika faktora rastresitosti usitnjenog materijala uočena je iz-

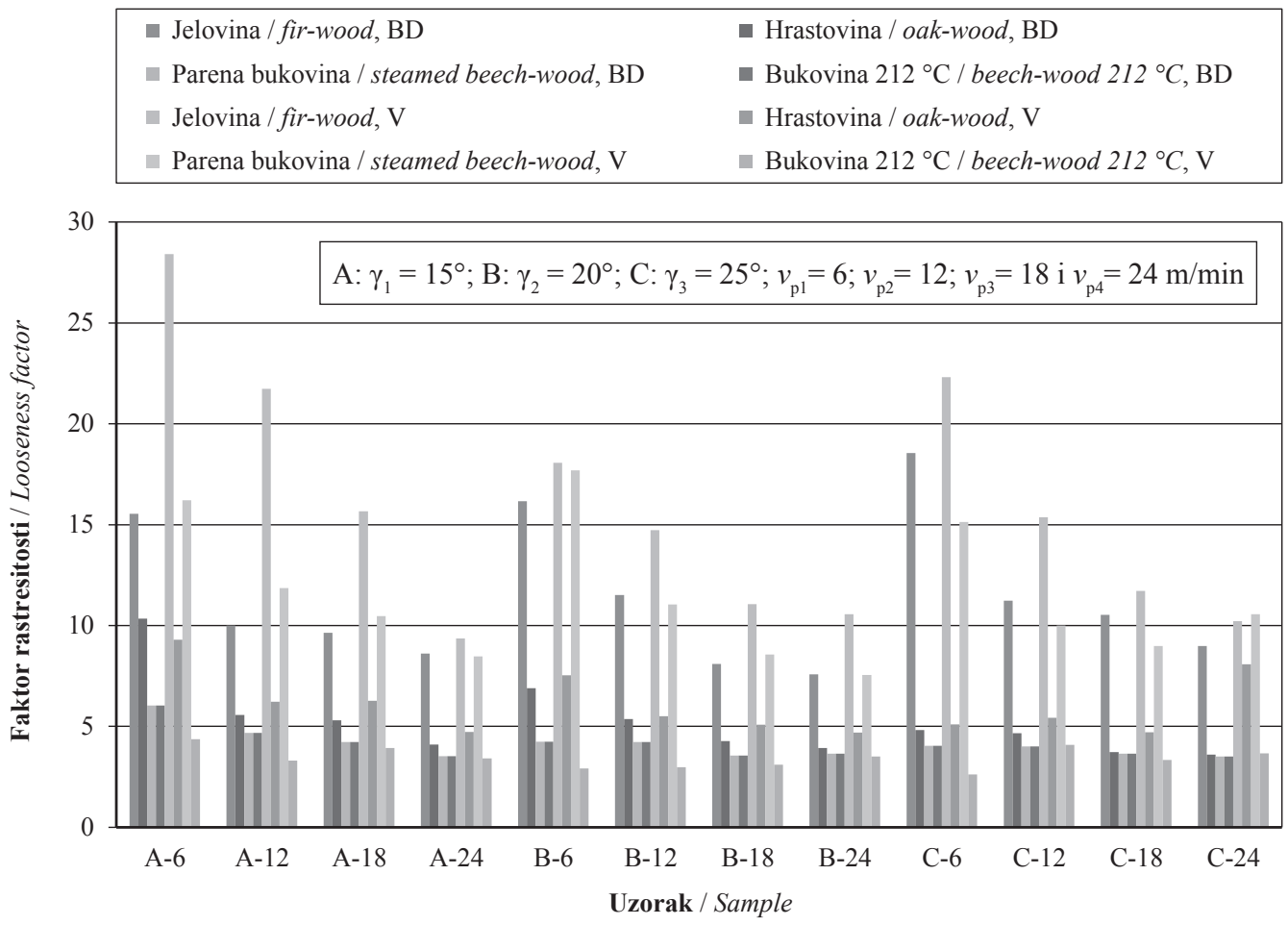

Slika 8. Usporedba faktora rastresitosti $\left(\rho_{\mathrm{k}} / \rho_{\mathrm{r}} \mathrm{i} V_{\mathrm{r}} / V_{\mathrm{k}}\right)$ svih uzoraka

Figure 8 Comparison of looseness factor $\left(\rho_{\mathrm{k}} / \rho_{\mathrm{r}} \mathrm{i} V_{\mathrm{r}} / V_{\mathrm{k}}\right)$ of all samples 
..... Jug, Beljo Lučić, Čavlović: Čimbenici koji utječu na rastresitost usitnjenog materijala...

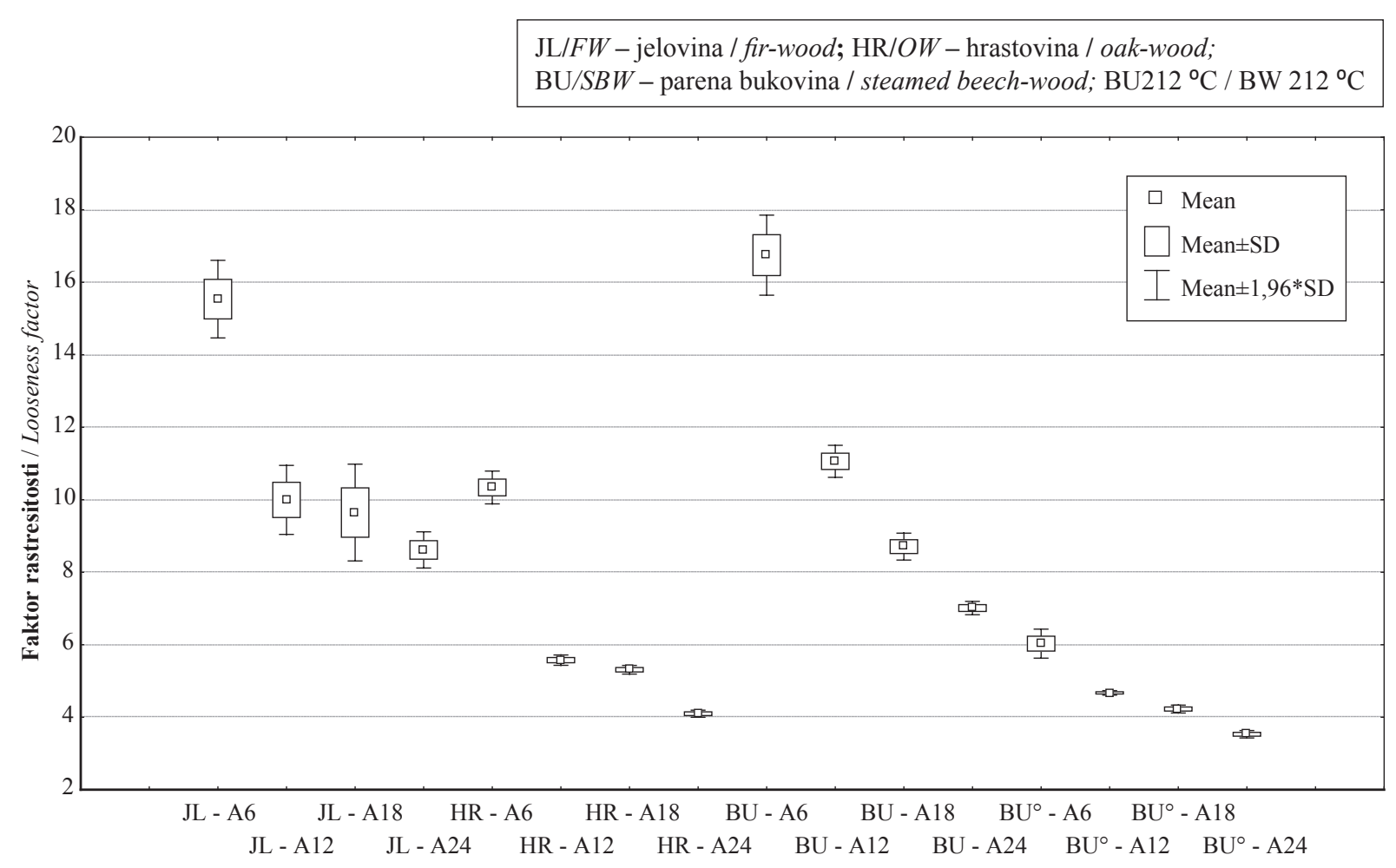

Skupine uzoraka - kut A / Sample groups - angle A

Slika 9. Usporedba faktora rastresitosti $\left(\rho_{\mathrm{k}} / \rho_{\mathrm{r}}\right)$ za ispitivane vrsta drva - kut A

Figure 9 Comparison of looseness factor $\left(\rho_{\mathrm{k}} / \rho_{\mathrm{r}}\right)$ of all wood species - angle A

među jelovine i termički modificirane bukovine. Jelovina ima faktor rastresitosti 3 do 10 puta veći od faktora rastresitosti termički modificirane bukovine (tabl. 5.).

Faktor rastresitosti blanjevine pri jednakom prednjem kutu oštrice značajno se razlikuje za sve pa- rove uzoraka osim za uzorke parene bukovine i jelovine $\left(p_{\gamma_{2}}=0,14\right)$ nastale pri posmičnoj brzini od $6 \mathrm{~m} /$ min. Također se statistički značajno razlikuju faktori rastresitosti za sve parove uzoraka dobivenih pri jednakoj posmičnoj brzini. U svim uvjetima blanjanja

JL/FW - jelovina / fir-wood; HR/OW - hrastovina / oak-wood; $\mathrm{BU} / \mathrm{SBW}$ - parena bukovina / steamed beech-wood; BU212 ${ }^{\circ} \mathrm{C} / \mathrm{BW} 212{ }^{\circ} \mathrm{C}$

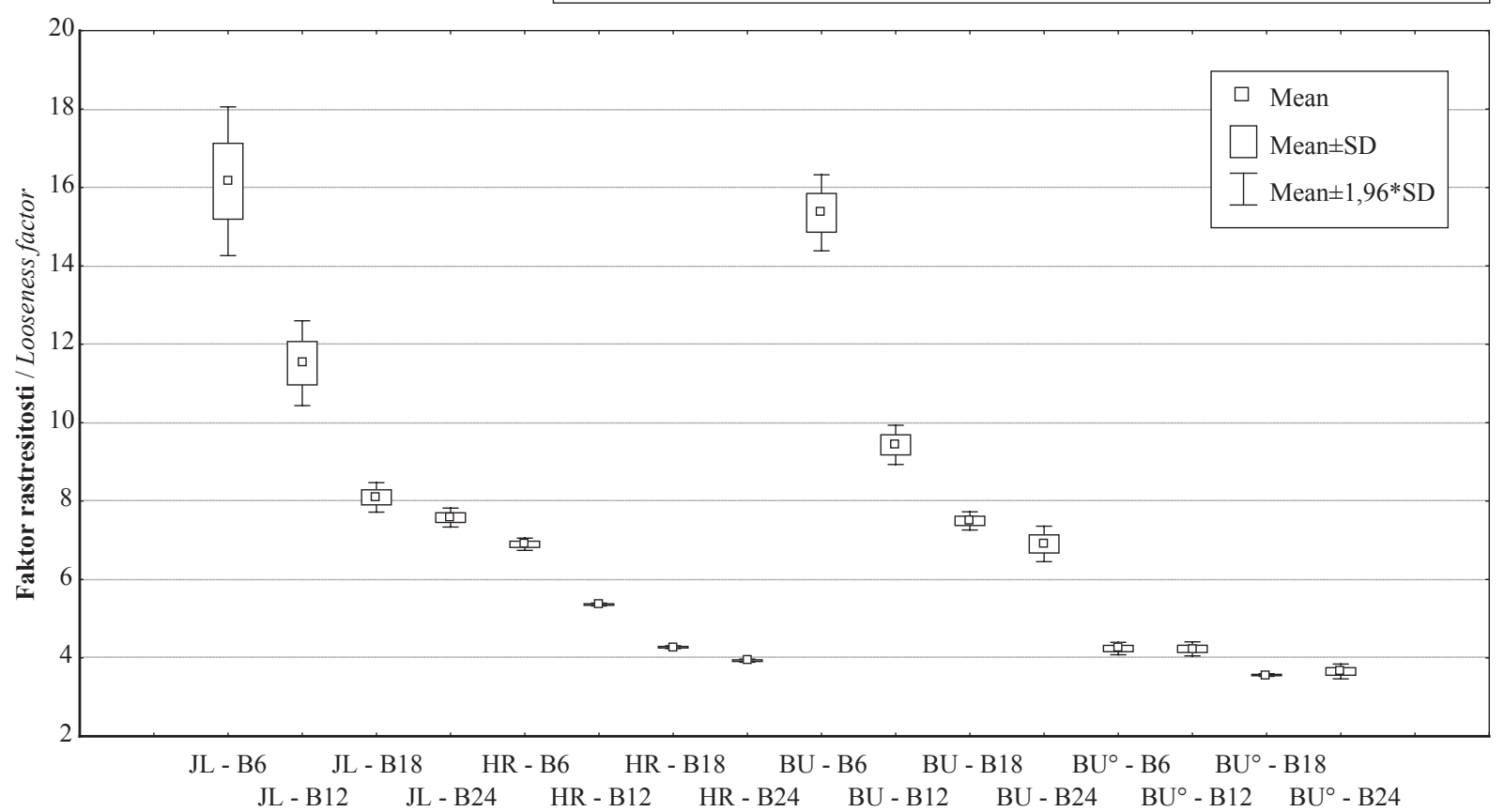

Skupine uzoraka - kut B / Sample groups - angle B

Slika 10. Usporedba faktora rastresitosti $\left(\rho_{k} / \rho_{r}\right)$ za ispitivane vrsta drva - kut B

Figure 10 Comparison of looseness factor $\left(\rho_{\mathrm{k}} / \rho_{\mathrm{r}}\right)$ of all wood species - angle B 
$\mathrm{JL} / F W$ - jelovina / fir-wood; HR/OW - hrastovina / oak-wood; $\mathrm{BU} / \mathrm{SBW}$ - parena bukovina / steamed beech-wood; $\mathrm{BU} 212{ }^{\circ} \mathrm{C} / \mathrm{BW} 212{ }^{\circ} \mathrm{C}$

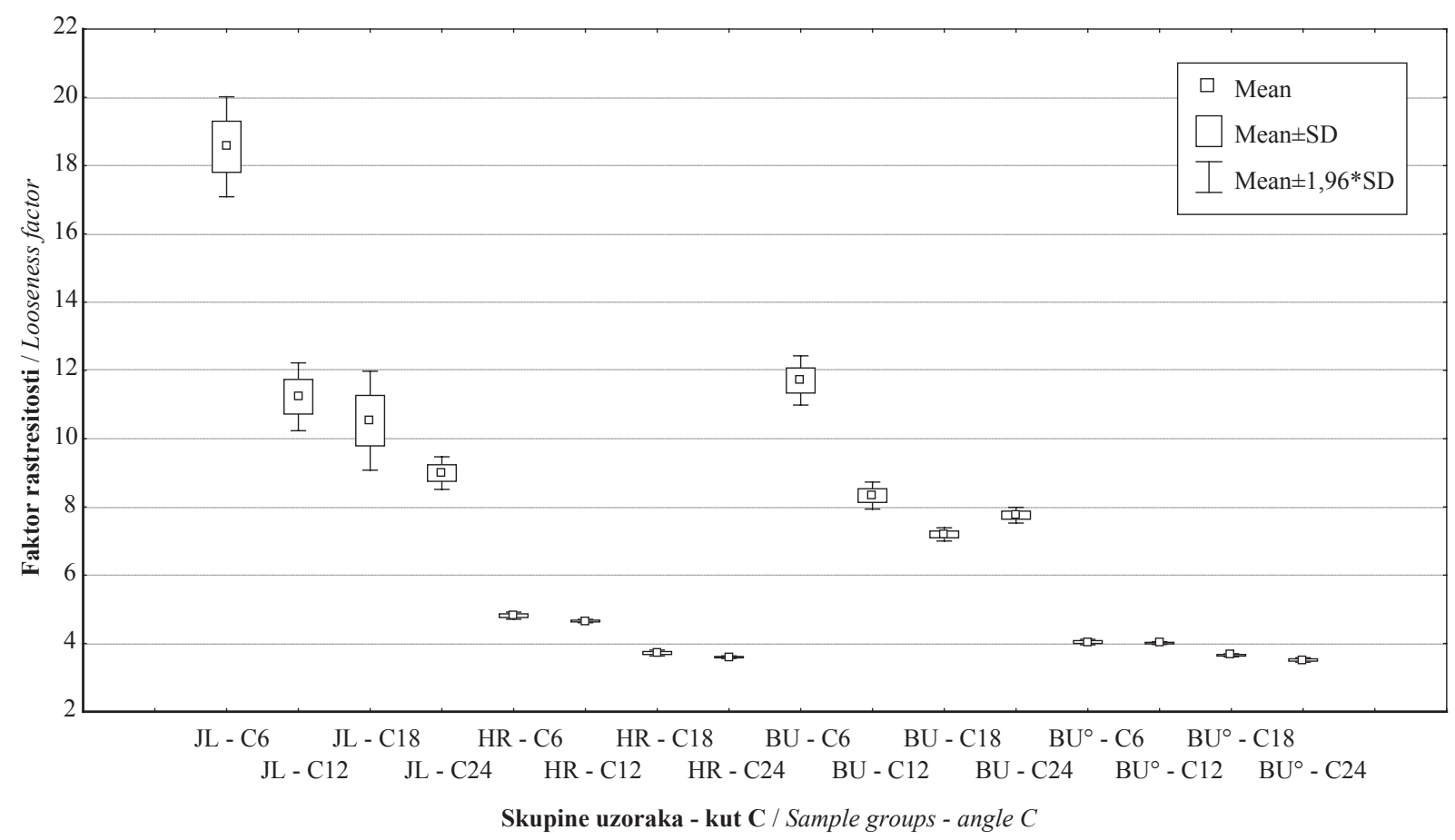

Slika 11. Usporedba faktora rastresitosti $\left(\rho_{\mathrm{k}} / \rho_{\mathrm{r}}\right)$ za ispitivane vrsta drva - kut $\mathrm{C}$

Figure 11 Comparison of looseness factor $\left(\rho_{\mathrm{k}} / \rho_{\mathrm{r}}\right)$ of all wood species - angle $\mathrm{C}$

značajno su se jače usitnile drvne čestice nastale obradom termički modificirane bukovine u usporedbi s ostalim vrstama drva. Takvi su rezultati posljedica smanjene čvrstoće cijepanja i povećane krtosti termički modificiranog drva (Feist i Sell, 1987.; Sailer i Rapp, 2000.; Rapp i Sailer, 2001.; Rep i Pohleven, 2001.; Sinn i dr., 2002.). Nešto se manje usitnjavaju čestice nastale obradom hrastovine, a najmanje čestice nastale obradom jelovine.

Nasipna gustoća usitnjenog materijala nastaloga pri blanjanju termički modificirane bukovine dva je do tri puta veća od nasipne gustoće blanjevine parene bukovine, a faktor rastresitosti manji joj je i do četiri puta. Razlog za to je izostanak karakterističnih spiralnih čestica pri obradi termički obrađene bukovine $\left(212^{\circ} \mathrm{C}\right)$ manjim posmičnim brzinama, $i$ to zbog krtosti materijala, što su pokazali i rezultati granulometrijske analize istih uzoraka (Beljo Lučić i dr., 2009.).

Uzimajući u obzir sve uzorke bez obzira na posmičnu brzinu i prednji kut oštrice, usporedbom faktora rastresitosti za ispitivane vrsta drva (sl. 9., 10. i 11.) zamijećen je značajan utjecaj vrste drva na faktor rastresitosti usitnjenog materijala. Iz dijagrama je vidljiva značajna razlika između podataka za sve vrste drva. Za sve prednje kutove oštrice faktor rastresitosti jelovine i parene bukovine odnosno hrastovine i termički modificirane bukovine bio je gotovo jednak, no ipak različit za sve skupine uzoraka.

I istraživanja Palmqvista i Gustafssona (1999.) pokazala su da pri blanjanju borovine, bukovine i MDF ploča pri jednakim debljinama strugotine znatan utjecaj na usitnjavanje materijala ima vrsta drva.

\section{ZAKLJUČAK \\ 4 CONCLUSION}

Poznavanje utjecaja parametara obrade drva na faktor rastresitosti dobivenoga usitnjenog materijala korisno je za odabir uvjeta blanjanja radi postizanja željene usitnjenosti tako nastaloga drvnog materijala. Analizom zahtjeva vezanih za usitnjeni drvni materijal (sa stajališta rukovanja njime, njegova transportiranja i skladištenja, trajnosti i kvalitete te udjela potencijalno lebdećih čestica) dolazi se do zaključka da je poželjnija blanjevina većeg faktora rastresitosti. Međutim, za takav je materijal potrebno više prostora za skladištenje, ali ga je lakše transportirati, manje su emisije lebdećih čestica u radni prostor, a takav materijal ima i bolju permeabilnost.

Sve veća produktivnost strojeva za obradu drva temelji se na velikim brzinama rezanja i velikim posmičnim brzinama. U ovom je istraživanju pokazano da pri obradi jelovine i parene bukovine povećanje posmične brzine pri konstantnoj brzini rezanja utječe na smanjenje faktora rastresitosti dobivenoga usitnjenog materijala. Pri blanjanju termički modificirane bukovine prednji kut oštrice i posmična brzina nemaju utjecaja na faktor rastresitosti usitnjenog materijala, ali je pri blanjanju termički obrađene bukovine koncentracija lebdećih čestica znatno veća nego pri blanjanju ostalih istraživanih vrsta drva. 


\section{LITERATURA \\ 5 REFERENCES}

1. Beljo Lučić, R.; Kos, A.; Antonović, A.; Vujasinović, E.; Šimičić, I., 2005: Svojstva usitnjenog materijala nastalog pri mehaničkoj obradi drva. Drvna industrija, 56 (1): 11-19.

2. Beljo Lučić, R.; Čavlović, A.; Ištvanić, J.; Đukić, I.; Kovačević, D., 2007: Granulometric analysis of chips generated from planing of different species of wood. 2nd International Scientific Conference ,Woodworking Techniques 2007", Zalesina, 207-213.

3. Beljo Lučić, R.; Čavlović, A.; Đukić, I., 2007: Factors influencing particle size distribution of oak and fir sawdust in circular sawing. Wood research, 52 (1): 35-46.

4. Beljo Lučić, R.; Čavlović, A.; Đukić, I.; Jug, M.; Ištvanić, J.; Škaljić, N., 2009: Machining properties of thermally modified beech-wood compared to steamed beech-wood. 3rd International Scientific Conference „Woodworking technique", Zalesina 2009, 313-322.

5. Dolny, S.; Rogozinski, T., 2011: Bulk characteristics of dust from pinewood sanding. 4th International Scientific Conference „Woodworking technique”, Prague, 2011, 86-92.

6. Feist, W. C.; Sell, J., 1987: Weathering Behavior of Dimensionally Stabilized Wood Treated by Heating under Pressure of Nitrogen Gas. Wood and Fiber Science, 19 (2): 183-195.

7. Hemillä, P.; Gottlöber, C.; Weelling, I., 2003: Effect of cutting parameters to dust and noise in wood cutting, laboratory and industrial tests. 16th International Wood Machining Seminar. Matsue, Japan, 375-384.

8. Horvat, I.; Krpan, J., 1967: Drvno industrijski priručnik, 401-474.

9. Kopecky, Z.; Rousek, M., 2007: Dustiness in high speed milling. Wood Research 52 (2): 65-76.

10. Madjarević, B., 1969: Rukovanje materijalom Unutrašnji transport - pakiranje - skladištenje. Zagreb, Tehnička knjiga, 201-203.

11. Očkajová, A.; Beljo Lučić, R.; Čavlović, A.; Teraňová, J., 2006: Reduction of dustiness in sawing wood by universal circular saw. Drvna industrija, 57 (3): 119-126.

12. Očkajová, A.; Beljaková, A.; Luptáková J., 2008: Selected properties of spruce dust generated from sanding operations. Drvna industrija, 59 (1): 3-10.
13. Palmqvist, J.; Gustafsson, S. I., 1999: Emission of dust in planing and milling of wood. Holz als Roh- und Werkstoff, 57: 164-170.

http://dx.doi.org/10.1007/s001070050035.

14. Rapp, A. O.; Sailer, M., 2001: Oil-heat-treatment of wood - process and properties. Drvna industrija, 52 (2): 63-70.

15. Rep, G.; Pohleven, F., 2001: Wood modification - a promising method for wood preservation, International Conference: Wood in construction industry: Tradition and future, Zagreb, Croatia, 25 April 2001, 27-38.

16. Sailer, M.; Rapp, A. O., 2000: Upgrading of wood by aplication of an oil-heat treatment. Holz als Roh- und Werkstoff, 58 (1-2): 15-22. http://dx.doi.org/10.1007/s001070050379

17. Sever, S., 1988: Transport u drvnoj industriji (interna skripta), 53-57.

18. Shang, D. K.; Yan, Q. Y.; Tan, H. P.; Sun, B. H., 1999: The experimental research and analysis of permeability of basalt and wood particle aggregates. Holz als Rohund Werkstoff, 57: 271-275. http://dx.doi.org/10.1007/s001070050057.

19. Sinn, G.; Gindl, M.; Reiterer, A., 2002: Ausgewählte materialphysikalische Eigenschaften von modifiziertem Holz, poglavlje u knjizi: Modifiziertes Holz: Eigenschaften und Märkte, Lignovisionen Band 3, September 2002, 171-189.

20. Varga, M.; Csanády, E.; Németh, G.; Németh, S. Z., 2004: Analysis of exhausted and remaining dust at workplaces applying CNC processing machinery. IV. Medzinarodna vedecka konferencia „Trieskove a beztrieskove obrabanie dreva '04", Stary Smokovec - Tatry, 131-137.

21. ***EN 13183-2:2008. Sadržaj vlage u piljenoj građi - 2 . dio: Ocjena metodom mjerenja električnog otpora.

\section{Corresponding address:}

Assist. MATIJA JUG, Ph.D.

Department of Process Techniques

Faculty of Forestry University of Zagreb

Svetošimunska c. 25

HR-10000 Zagreb, CROATIA

e-mail:mjug@sumfak.hr 